\title{
Tussen partij en parlement: het profiel van de fractievoorzitter in België
}

\author{
Benjamin de Vet en Bram Wauters
}

\section{ABSTRACT: Between Party and Parliament: The Profile of the Leader of the Parliamentary Party in Belgium}

The leader of the parliamentary party in Belgium is a very specific position, which differs from the political leader and the organizational leader of a party. This person acts as a crucial linking pin between 'the party in central office' and 'the party in public office'. Owing to an increase in power of 'the party in central office' in modern 'cartel parties', we expect repercussions on the profile, selection and functioning of parliamentary party leaders. In this first, exploratory analysis based on a new dataset, we sketch the profile of these leaders in terms of experience and career, and based on these characteristics, we develop a typology. We also investigate whether these variables vary over time and by government status.

Our results show for most of the indicators a weakening of the parliamentary party leader over time, whereas government parties appear to prefer a stronger parliamentary party leader than opposition parties.

KEYWORDS: political party, parliament, parliamentary party, leader, political elites, Belgium

\section{Inleiding}

Politieke partijen zijn cruciale politieke actoren in zowat alle moderne democratieën (Luther \& Müller-Rommel, 2005; Katz, 2005). Dit is zeker het geval in particratieën als België of Italië, waar partijen meer dan andere actoren de politieke besluitvorming determineren (Dewachter, 2002; De Winter, Della Porta \& Deschouwer, 1996; Steyvers, 2014). Hoewel ze vaak lijken te handelen als unitaire actoren, zijn politieke partijen organisaties met meerdere 'gezichten', die niet noodzakelijk dezelfde doelstellingen en belangen vooropstellen (Katz, 2005; Katz \& Mair, 1994). 
Deze drie partijgezichten zijn de 'party on the ground' (de leden- en nevenorganisaties), de 'party in central office' (de centrale partijleiding en het partijsecretariaat) en de 'party in public office' (de regerings- en parlementsleden van de partij).

In de voorbije decennia hebben verschillende maatschappelijke en politieke evoluties de interne machtsverhoudingen binnen partijen danig door elkaar geschud. Onderzoekers focussen hierbij vaak op de gewijzigde positie van de 'party on the ground', die o.m. ten gevolge van de toenemende individualisering en secularisatie in crisis lijkt te verkeren (Dalton, McAllistar \& Wattenberg, 2005; Poguntke, 2005). Dit uit zich o.a. in slinkende ledenaantallen (Van Biezen, Mair \& Poguntke, 2012), sterk toegenomen electorale volatiliteit (Dassoneville \& Baudewyns, 2014; Drummond, 2006), en in een dalend vertrouwen in politieke partijen (Dalton \& Weldon, 2005). De twee overige partijgezichten - de 'party in central office' en de 'party in public office' - en vooral hun onderlinge relatie, blijven echter veelal onderbelicht. Nochtans hebben ook hier verschuivingen plaatsgevonden, waarbij vooral de macht van de 'party in central office' sterk toegenomen lijkt te zijn.

In de periode na de Tweede Wereldoorlog vervaagden de scherpe klassentegenstellingen onder impuls van de economische hoogconjunctuur, de uitbouw van de sociale welvaartsstaat en daaruit volgend de opkomst van een brede middenklasse (Katz \& Mair, 1995; Krouwel, 2006). Duvergers' 'massapartij' (1954), voornamelijk gericht op de vertegenwoordiging van een bepaalde classe gardée, met een grote, homogene lidmaatschapsbasis, moet hierdoor geleidelijk aan plaats ruimen voor de electoraal-professionele 'catch-all partij' (Kircheimer, 1966; Krouwel, 2006). Deze 'catchallisering' gaat niet enkel gepaard met een electorale verbreding en de reductie van de ideologische bagage van partijen. Ook op organisatorisch vlak zien we twee belangrijke evoluties (Katz, 2005; Krouwel, 2006). Ten eerste wordt de interne beslissingsmacht steeds meer gecentraliseerd bij de partijtop. Ten tweede stelt men een hoge mate van professionalisering van de partijcentra vast: het verlies aan partijleden wordt opgevangen door een toegenomen aantal fulltime partijmedewerkers. Deze machtscentralisatie en professionalisering gaan zelfs nog een stap verder bij de 'cartel party', waarbij politieke partijen veranderen in 'agents of the state' en waarbij de nadruk ligt op de efficiëntie en effectiviteit van het bestuur en de managementcapaciteiten van de politici (Katz \& Mair, 1995). De complexe federale staat die België is, versterkt de macht van de centrale partij omdat zij een sleutelrol speelt bij het op elkaar afstemmen van diverse (partij-)actoren op de verschillende beleidsniveaus (Steyvers, 2014).

In contrast met de sterk geprofessionaliseerde partijcentra die alsmaar meer macht naar zich toe trekken, worden het parlement en de fracties van partijen - als onderdeel van de 'party in public office' - vaak als eerder zwakke actoren binnen het politieke systeem gezien. Dit is zeker het geval in België (Depauw, 2005; Dewachter, 2002; De Winter \& Dumont, 2000). Politieke partijen (meer specifiek de 'parties in central office') domineren de dagelijkse activiteiten van het 
parlement. Partijen beschouwen zichzelf als afgevaardigden van hun kiezers en proberen de parlementaire fractie aan het partijprogramma en aan een eventueel bestuursakkoord te houden. De beperkte bewegingsruimte van de parlementsleden komt het best tot uiting in de hoge mate van fractiediscipline en het beperkte aantal dissidente stemmen binnen parlementaire fracties (Depauw, 2005). Het feit dat partijcentra nu zelf expertise hebben opgebouwd over een breed gamma aan beleidsthema's (Pattyn et al., 2014) zou bovendien kunnen betekenen dat ze minder afhankelijk zijn geworden van de ervaring en knowhow van parlementsleden, wat de invloed van de parlementaire fractie verder reduceert.

Belgie is altijd al een land geweest met een sterke dominantie van partijen (De Winter \& Dumont, 2000), terwijl in Nederland de parlementaire fractie meer macht heeft en er soms zelfs sprake is van een 'fractiocratie' (Andeweg, 2000). Ondanks duidelijke verschillen tussen landen, kan er algemeen toch een trend genoteerd worden in de richting van een sterkere dominantie van de centrale partij ten aanzien van de parlementaire fractie (Heidar, 2013; Heidar \& Koole, 2000), waarbij die dominantie in het ene land verregaander is dan in het andere.

De positie van de fractievoorzitters is in België bijzonder relevant bij het onderzoeken van de delicate relatie tussen de 'party in central office' en de 'party in public office'. Hij of zij vervult immers een belangrijke brugfunctie tussen deze twee partijgezichten: de fractievoorzitter geeft leiding aan een parlementaire fractie (zijnde de 'party in public office'), maar is tegelijkertijd vaak statutair lid van het partijbureau, een bijzonder machtig orgaan van de 'party in central office' (Dewachter \& Depauw, 2006). Omwille van de bijzondere positie die hij of zij inneemt binnen de partij, kan de fractievoorzitter een belangrijke spreekbuis zijn voor parlementsleden die hun mening of grieven willen delen met de partijtop, of beslissingen van hogerop willen beïnloeden. Omgekeerd is de fractievoorzitter tegelijkertijd een essentieel figuur voor de partijelite. Hij of zij moet de fractiediscipline handhaven en de congruentie tussen het wetgevend werk en de algemene partijlijnen - uitgevaardigd door het partijbestuur - waarborgen (De Winter, 1998).

Het ligt bijgevolg in de lijn der verwachtingen dat de gewijzigde machtsbalans tussen centrale partij en fractie (zoals hierboven beschreven) gevolgen kan hebben voor de fractieleider. Zo is het interessant om te onderzoeken wat de weerslag van de toegenomen macht van de centrale partij is voor de verwachtingen die de partijelite heeft over de fractievoorzitter, voor de criteria die gehanteerd worden bij zijn/haar selectie, voor de personen betrokken bij dat selectieproces, voor de rolinvulling die de fractieleider zelf geeft aan zijn mandaat (zie bv. Searing, 1994), en voor de carrièrekenmerken van de fractieleider.

In deze eerste, verkennende studie verdiepen we ons in het profiel van de fractieleiders. We trachten de voornaamste politieke carrièrekenmerken van de fractievoorzitters in de Kamer van Volksvertegenwoordigers, de Senaat en het Vlaams Parlement bloot te leggen, waarna we nagaan of deze carrièrekenmerken de voorbije 
decennia zijn gewijzigd. Een afgetekende verandering in hun politiek profiel zou een eerste aanwijzing kunnen zijn voor een eventueel gewijzigde rol van de fractieleiders in België en een gewijzigde relatie tussen de 'party in central office' en de 'party in public office', in het kader van de hierboven vernoemde machtscentralisering en professionalisering op het niveau van de 'party in central office'. Daarnaast gaan we na of het profiel van de fractievoorzitter verschilt tussen regerings- en oppositiepartijen. De positie van een fractievoorzitter is immers crucialer voor regeringspartijen, aangezien daar niet enkel de partijlijn in het geding is maar ook het naleven van het regeerakkoord, gesloten tussen de verschillende regeringspartijen.

Het is evenwel niet duidelijk in welke richting de versterking van de 'party in central office' doorheen de tijd doorwerkt op het profiel van de fractieleider. Men zou kunnen argumenteren dat partijen een zwakke fractieleider verkiezen, omdat deze weinig weerwerk vanuit de parlementaire fractie zal brengen. Men zou evenwel evengoed kunnen beweren dat een sterke fractieleider interessant is voor een partij, omdat deze beter in staat moet worden geacht om de fractie in het gareel te doen lopen. We onderzoeken dus het profiel van de fractieleider zonder daar evenwel duidelijke hypothesen rond te kunnen formuleren over evoluties doorheen de tijd. Dit geldt evenzeer voor het effect van regeringsdeelname. Bij regeringspartijen is het handhaven van partijdiscipline belangrijker dan bij oppositiepartijen. Enerzijds zouden we daarom kunnen verwachten dat regeringspartijen eerder zullen opteren voor sterke figuren. Anderzijds staat daar tegenover dat een zwakke fractieleider minder weerwerk zal bieden bij het bepalen van het partijstandpunt en de partijstrategie, zodat de partijleiding zelf autonomer kan optreden.

In dit artikel gaan we als volgt te werk. Vooreerst gaan we verder in op de specificiteit van het fractievoorzitterschap in België. Daarvoor plaatsen we het fractievoorzitterschap kort in een internationaal-comparatief perspectief. We bekijken welke formele regels er binnen het parlement en binnen partijen bestaan met betrekking tot deze functie. Ten tweede zetten we kort uiteen welke politieke carrièrekenmerken voor dit onderzoek relevant zijn en wat de betekenis kan zijn van eventuele wijzigingen in dit profiel. Daarna gaan we over tot de eigenlijke analyse van het politieke profiel van de fractieleiders. Hiervoor werd een dataset opgemaakt van alle parlementsleden die ooit fractievoorzitter zijn geweest in het Vlaams Parlement, de Kamer van Volksvertegenwoordigers en de Senaat ( $\mathrm{n}=$ 265). Aan de hand van de biografische dossiers ${ }^{1}$ van deze personen wordt onderzocht hoe lang ze fractievoorzitter zijn geweest, wat hun leeftijd was op het moment van aantreden, hoeveel parlementaire en ministeriële ervaring deze personen hadden en hoelang ze fractieleider zijn gebleven. Ten slotte onderzoeken we welk politiek mandaat de fractieleiders opnamen direct na het fractievoorzitterschap. Door de onderzochte periode onder te verdelen in decennia, bekijken we of deze politieke kenmerken zijn geëvolueerd sinds 1962, het jaar waarin de eerste fractieleider officieel aantrad in de Kamer. 


\section{Het fractievoorzitterschap in België}

Vooraleer we verder ingaan op het politieke profiel van de fractieleiders, is het belangrijk te vermelden dat het fractievoorzitterschap in België een bijzondere politieke functie is. Deze functie valt immers niet samen met die van de politieke leider van een partij, noch met het voorzitterschap van de partijorganisatie, wat in andere landen wel vaak het geval is (Pilet \& Wauters, 2014). Zo is de fractievoorzitter in landen die het 'Westminstermodel' volgen (zoals Groot-Brittannië, Australië en Canada) vaak ook de politieke leider en het electorale boegbeeld van de partij (tenzij de politieke leider deel uitmaakt van de regering). De voorzitter van de partijorganisatie ('party in central office') daarentegen, is in die landen een andere persoon die veeleer een louter organisatorisch takenpakket heeft (Pilet \& Cross, 2014). In Nederland vinden we een soortgelijke logica terug. In enkele andere landen, zoals in Oostenrijk en Spanje, is de fractievoorzitter tevens partijvoorzitter én politiek leider van de partij.

In België is de situatie echter anders en vrijwel uniek. De fractieleider is in België niet de politieke noch de organisationele leider van de partij. Het is de partijvoorzitter, die naast het organisatorisch hoofd, meestal ook de voornaamste politieke leider van de partij is (Fiers, 1998). De fractieleider leidt de parlementaire fractie en neemt een intermediaire positie in tussen de partijelite (waartoe ook de partijvoorzitter behoort) en de parlementaire fractie (Pilet \& Wauters, 2014). Hij of zij is als het ware de brug tussen de 'party in central office' en de 'party in public office'.

Meer gelijkaardig, maar niet geheel hetzelfde als in België, is de positie van de 'whips' in Westminsterdemocratieën. De 'chief whips', die worden bijgestaan door de 'junior whips', vormen er de link tussen de partijleiders en de backbenchers, ze managen het parlementaire werk en zorgen voor partijcohesie en -discipline (Bowler, Farrell \& Katz, 1999; Searing \& Game, 1977; Westmacott, 1983). In tegenstelling tot de fractieleiders, zijn er meerdere 'whips' per fractie. 'Whips' genieten doorgaans prestige en hebben een grote morele autoriteit, maar ze zijn niet de leiders van de 'parties-in-parlement' (cf. supra), wat een belangrijk verschilpunt is met de fractieleiders in België. Ze werken voornamelijk in de luwte, krijgen relatief weinig media-aandacht en worden benoemd door en zijn verantwoording verschuldigd aan de ware parlementaire leiders: de partijleiders (Searing \& Game, 1977; Westmacott, 1983).

Als ware leider van de politieke fractie én als brugpersoon tussen de 'party in public office' en de 'party in central office', biedt de positie van de fractievoorzitters in het Belgische politieke systeem ons met andere woorden een unieke kans om de verhouding tussen de bovengenoemde partijgezichten verder uit te klaren. We belichten nu eerst verder de formele regels met betrekking tot het fractievoorzitterschap, bekeken vanuit het oogpunt van het parlement en van de partij. 
TABEL 1. Formele bepalingen betreffende het fractievoorzitterschap in de partijstatuten.

\begin{tabular}{|c|c|c|c|c|c|}
\hline & Statutaire lidmaatschappen & Aanstelling & Taken & Onverenig-baar met & Varia \\
\hline Open VId & $\begin{array}{l}\text { - Lid partijbureau* } \\
\text { - Lid partijraad }\end{array}$ & - & $\begin{array}{l}\text { Zit fractie voor. (En fractie bepaalt } \\
\text { politieke lijn, in samenspraak met partij- } \\
\text { bestuur en in over-eenstemming met het } \\
\text { partijprogramma). }\end{array}$ & - & $\begin{array}{l}\text { Partijcongres kan fractieleiders } \\
\text { verantwoording laten afleggen }\end{array}$ \\
\hline Sp.a & $\begin{array}{l}\text { - Lid partijbureau* } \\
\text { - Lid uitvoerend bestuur } \\
\text { - Lid partijraad }\end{array}$ & - & $\begin{array}{l}\text { 'Fractie' geeft verslag activiteiten op } \\
\text { partijbureau }\end{array}$ & Partijvoorzit-terschap & $\begin{array}{l}\text { Partijbureau vertegenwoordigd } \\
\text { op fractievergade-ringen }\end{array}$ \\
\hline$C D \& V$ & $\begin{array}{l}\text { - Lid partijbureau } \\
\text { - Lid uitvoerend Bestuur } \\
\text { - Lid partijraad }\end{array}$ & - & $\begin{array}{l}\text { Fractievoorzitter zorgt voor: } \\
\text { - Goed functioneren fractie } \\
\text { - Taakverdeling } \\
\text { - Samenwerking met de partij } \\
\text { - Contacten met maatschappelijke } \\
\text { organisaties } \\
\text { - Vertolking van de partijstandpunten. } \\
\text { - Coördinatie met partijprogramma }\end{array}$ & - & $\begin{array}{l}\text { - Lid commissie christendemo- } \\
\text { cratie } \\
\text { - Fractievoorzitter woont } \\
\text { met stip partijbureau bij, } \\
\text { partijvoorzitter de fractiever- } \\
\text { gaderingen } \\
\text { - Bepalingen relatie fractie- } \\
\text { partij (art. 66-68). }\end{array}$ \\
\hline$N-V A$ & $\begin{array}{l}\text { - Lid partijbureau } \\
\text { - Lid partijraad }\end{array}$ & - & - & $\begin{array}{l}\text { Lidmaat-schap uitvoerend } \\
\text { bestuur }\end{array}$ & - \\
\hline Groen & $\begin{array}{l}\text { - Lid partijbureau** } \\
\text { - Lid partijraad }\end{array}$ & $\begin{array}{l}\text { Fractievoor-zitter } \\
\text { wordt aangeduid } \\
\text { door de fractieleden }\end{array}$ & $\begin{array}{l}\text { Uitvoering geven en initiatief nemen } \\
\text { binnen politieke krachtlijnen door de } \\
\text { partijraad en - congres bepaald. }\end{array}$ & - & $\begin{array}{l}\text { Partijbureau kan fractievoorzitter } \\
\text { interpelleren en evalueren }\end{array}$ \\
\hline Vlaams Belang & Lid partijbureau & - & - & - & - \\
\hline
\end{tabular}

(*) Met adviserende stem

${ }^{* *}$ Enkel fractievoorzitters Kamer en Vlaams Parlement 
We beginnen met het parlement. Politieke fracties - en bijgevolg de leiders van deze fracties - staan centraal in de dagelijkse werking van de federale en regionale parlementen. Formele regels omtrent het fractievoorzitterschap zijn er echter vrij weinig. In de reglementen van de Kamer van Volksvertegenwoordigers, de Senaat en het Vlaams Parlement vinden we drie soorten formele bepalingen terug.

De eerste soort heeft betrekking op de aanwijzing van de fractievoorzitters: "De volksvertegenwoordigers kunnen politieke fracties vormen. De politieke fracties overhandigen aan de voorzitter van de Kamer de lijst van hun leden en geven de naam van hun fractievoorzitter op" (Reglement van de Kamer van Volksvertegenwoordigers, 2014, p. 18). Eenzelfde procedure wordt gehanteerd in de Senaat en in het Vlaams Parlement. Hoewel de fractieleider formeel wordt verkozen door en onder de leden van de fractie, heeft de partijleiding een belangrijke invloed op wie wordt aangesteld als fractievoorzitter. Dit verklaart waarom er zo vaak een consensus-kandidaat, die het volledige vertrouwen van de partijtop geniet, naar voren wordt geschoven (De Winter \& Dumont, 2000).

Een tweede soort bepalingen heeft betrekking op de formele rol van de fractievoorzitter in het dagelijks bestuur van de betrokken parlementen. In Kamer en Senaat maken de fractieleiders deel uit van het Bureau en in het Vlaams Parlement maken de voorzitters van de erkende fracties deel uit van het 'Uitgebreid Bureau' (Reglement van de Kamer van Volksvertegenwoordigers, 2014; Reglement van de Senaat, 2014, p. 23; Reglement van het Vlaams Parlement, 2014, p, 35). Dit zijn belangrijke beheersorganen van de betrokken parlementaire vergaderingen (Devos \& Mus, 2011). In de Kamer maken de fractievoorzitters ook deel uit van de Conferentie van Voorzitters, een politiek orgaan dat vooral instaat voor de regeling van de werkzaamheden van de plenaire vergadering.

We kunnen nog een derde soort formele bepalingen onderscheiden, al is deze louter administratief van aard: het is fractieleider die een wijziging in de samenstelling van zijn politieke fractie en in de wijziging van commissielidmaatschap moet mededelen aan de parlementsvoorzitter.

De fractievoorzitters worden dus nauwelijks expliciet vermeld in de reglementen van de parlementaire instellingen. Nochtans weten we dat de fractieleider een spilfiguur is binnen de federale en regionale parlementen (De Winter \& Dumont, 2000). Zijn positie lijkt hierbij echter veelal gebaseerd te zijn op informele gebruiken. De fractievoorzitter leidt de fractievergaderingen, bepaalt de beleidslijn, kan woordvoerder zijn in de plenaire debatten of een woordvoerder aanstellen, en zorgt voor fractiediscipline. Als fractieleiders tot de regeringspartijen behoren, vormen ze daarnaast ook de verbinding met de regering en oefenen ze een sterke invloed uit op het handhaven van de parlementaire meerderheid (De Winter, 1992; Witte, 1996, p. 244).

Het parlement is echter niet het enige terrein waarop de fractievoorzitter een grote rol speelt. Ook binnen de partijorganisatie is de rol van de leider van de 
parlementaire fracties aanzienlijk. Om deze reden bekijken we, ten tweede, de formele bepalingen met betrekking tot het fractievoorzitterschap die staan beschreven in de statuten van de partijen die een erkende fractie hebben in het Vlaams Parlement, met name: sp.a, Open Vld , CD\&V, N-VA, Groen en Vlaams Belang. Onderstaand schema biedt een overzicht van de formele partijbepalingen die betrekking hebben op de fractievoorzitters in de federale en deelstaatparlementen. ${ }^{2}$

De statuten van alle onderzochte partijen behandelen het lidmaatschap van fractievoorzitters in de bestuursorganen van de partij. In alle politieke partijen zetelen de fractievoorzitters statutair in het partijbureau (zij het soms enkel met raadgevende stem, zoals bij Open Vld en sp.a). Bij Groen zetelen enkel de voorzitters van de Kamerfractie en van de fractie van het Vlaams Parlement statutair in het partijbureau. Het feit dat fractievoorzitters in alle partijen automatisch lid zijn van het partijbureau, is een duidelijke illustratie van de brugfunctie die fractieleiders vervullen.

Voor de rest zijn de bepalingen over de fractievoorzitters in de statuten eerder uiteenlopend, zowel qua aantal als qua aangesneden onderwerpen. Nieuwe partijen (zoals N-VA, VB en Groen) geven een eerder beperkte omschrijving, terwijl traditionele partijen (zoals CD\&V, sp.a en Open VLD) dit over het algemeen iets uitgebreider doen.

Zo behandelen de statuten van N-VA de rol van de fractievoorzitters minimaal. Er wordt aangegeven dat ze zetelen in het partijbureau en geen deel kunnen uitmaken van het dagelijks bestuur van de partij, maar over hun verplichtingen en taken lezen we bij N-VA niets.

Het andere uiterste vinden we bij CD\&V. De statuten van de christendemocraten weiden zeer gedetailleerd uit over de rol van de fractievoorzitter binnen de partijorganisatie. In de eerste plaats moet hij/zij zorgen voor het goed functioneren van de fractie, maar vooral de verantwoordelijkheid van de fractievoorzitter met betrekking tot de verhouding tussen de partij en de fractie wordt benadrukt. Een voorbeeld hiervan is het feit dat de leden van de parlementaire fracties van CD\&V hun fractievoorzitter vooraf in kennis moeten stellen van elk wetsvoorstel, amendement of elke interpellatie, "opdat hij in staat zou zijn hen elke passende aanwijzing te geven, de studiedienst en de Algemene Vergadering in te lichten, en desgevallend door hun zorgen, het wetsvoorstel op punt te zetten, te waken over de coördinatie van de parlementaire activiteit met de algemene partijleiding en de overeenstemming met het partijprogramma te bewerkstelligen" (Partijstatuten $C D \& V$, art. 65.3). Overigens besteden de statuten eveneens aandacht aan het feit dat ook de partij verplichtingen heeft ten aanzien van de fractie: de partij zal zich terughoudend opstellen en de eigen verantwoordelijkheid van de verkozenen respecteren. 


\section{Welke carrièrekenmerken zijn relevant?}

De formele regels, zowel deze van het Parlement als die van de partijen, vertellen ons relatief weinig over het functioneren van fractieleiders. Een analyse van de rolverwachting en rolinvulling van fractieleiders, van het selectieproces om hen aan te duiden en van hun profiel kan hier meer duidelijkheid scheppen. In dit artikel gaan we dieper in op het profiel van de fractieleiders. Belangrijk hierbij is de vraag: wat zijn de kenmerken van een sterke fractieleider?

Omdat specifieke literatuur naar de sterkte van fractieleiders schaars is, hanteren we een ruimer perspectief en bekijken we hoe andere auteurs sterkte van politici in het algemeen hebben ingevuld.

Enerzijds zijn er studies over effecten van leiders en hun kenmerken op verkiezingsuitslagen (Hayes, 2005; van Holsteyn \& Andeweg, 2010), waarbij de focus vaak ligt op (percepties van) psychologische kenmerken (leiderschap, empathisch vermogen, etc.) en hoe deze het aantal stemmen beïnvloeden. Deze benadering is voor dit artikel minder relevant, aangezien fractieleiders niet rechtstreeks in de electorale arena functioneren (enkel in hun hoedanigheid als parlementslid).

Andere auteurs hebben aandacht besteed aan de sterkte van politici in de besluitvorming. Zo ging Tsebelis (1995) na onder welke omstandigheden beleidsverandering tot stand kan komen. Hij legt sterk de nadruk op omgevingsfactoren. Hij besteedt veel aandacht aan institutionele factoren (presidentieel of parlementaire stelsel maar ook aan de context waarin beleid tot stand komt (aantal spelers, onderlinge overeenstemming tussen die spelers en steun van de achterban). Als het aantal spelers beperkt is, de overeenstemming groot en de cohesie met de achterban groot, dan kan een politicus zwaar wegen op de besluitvorming. Kaarbo (1997) argumenteert dat naast formele bepalingen (zoals besluitvormingsregels) persoonlijkheidskenmerken en leiderschapsstijl (consensuszoeker, taakgerichte leider, manager, ...) belangrijke elementen zijn om te bepalen hoe zwaar een regeringsleider kan wegen in het buitenlands beleid van zijn land. Persson en Hermansson (2013) schuiven enkele indicatoren naar voren die de positie van ministers verstevigen ten opzichte van de eerste minister. Zij stellen dat o.m. institutionele factoren (zoals het aantal ministers, eventuele formele beperkingen van de macht van de eerste minister, het aantal regeringspartijen) en socio-demografische kenmerken (zoals parlementaire achtergrond, politieke ervaring, de positie binnen hun partij) bepalen of een minister sterk weegt of niet.

Toegepast op de parlementaire setting, stellen Searing en Game (1977) dat de 'whips' in het Britse Lagerhuis, als manager van de 'party in parliament', zowel het vertrouwen van de partijleiders als van de backbenchers moeten weten te veroveren en hiervoor over bepaalde kwaliteiten moeten beschikken. Naast psychologische kwalificaties (zoals sociale vaardigheden, partijloyaliteit, het kunnen overstijgen van interne facties) en sociaal-demografische kenmerken (zoals sociale klasse 
en opleiding) zijn vooral parlementaire criteria, waaronder ervaring, belangrijk. Whips moeten letterlijk het klappen van de zweep kennen: ze moeten zich meester hebben gemaakt van zowel de formele regels en parlementaire procedures als van de meer informele gebruiken en breuklijnen binnen het parlement en de partij.

Ook Depauw en Fiers (2008) stellen politieke ervaring voorop als belangrijke eigenschap. Sinds de jaren 60 is de zwakke positie van het parlement ten opzichte van de uitvoerende macht voer geweest voor heel wat politiek-wetenschappelijke studies. Een dergelijk onderzoek focust voornamelijk op de afnemende rol van parlementen als wetgever (o.a. Depauw, 2005; Norton, 1993), wat zich onder andere vertaalt in het feit dat het merendeel van de wetgevende initiatieven (gemiddeld zo'n $85 \%$ ) niet afkomstig is van het parlement maar van de regering (Dewachter, 2002). De macht van parlementsleden in België, maar ook in andere moderne democratieën, is dus veeleer beperkt. Depauw en Fiers (2008) stellen hier echter tegenover dat parlementsleden via hun deskundigheid en dossierkennis informeel invloed kunnen uitoefenen op degenen die over meer beslissingsmacht beschikken. Cruciaal hierbij is politieke ervaring. In hun onderzoek, dat de periode van 1981-2008 overspant, komen Depauw en Fiers echter tot de conclusie dat de Belgische Kamerleden steeds minder kunnen terugvallen op hun ervaring, aangezien zowel de externe turnover (een grotere circulatie van verkozenen), als de interne turnover (het wijzigen van commissielidmaatschap) alsmaar toeneemt. Het federale parlement verliest hiermee gestaag een belangrijk wapen tegen de vaak relatief onervaren leden van de uitvoerende macht.

Samenvattend kunnen we drie groepen van factoren onderscheiden die de sterkte van politieke actoren bepalen: institutioneel-formele factoren, psychologische factoren (zoals leiderschapsstijl) en socio-demografische factoren (met bijzondere aandacht voor de rol van ervaring).

Voor dit artikel, dat een analyse maakt van de fractieleider binnen één land met eenzelfde politiek systeem, zijn institutioneel-formele factoren in grote mate constant, en dus minder relevant. Psychologische factoren zijn erg relevant, maar moeilijk om te meten, zeker als het gaat over fractieleiders uit het (verre) verleden. Vandaar dat we in dit artikel vooral focussen op de socio-demografische en politieke kenmerken van fractieleiders om te bepalen hoe zwaar ze wegen in het besluitvormingsproces.

Het belang dat o.m. Searing en Game (1977) en Depauw en Fiers (2008) hechtten aan 'ervaring' zal eveneens onze invalshoek zijn bij de analyse van de evolutie van het profiel van de fractievoorzitter. Fractieleiders moeten niet enkel opboksen tegen de leden van de uitvoerende macht maar evenzeer tegen de eigen partijtop. Ze kunnen hun politieke ervaring uitspelen om zichzelf en hun fractie meer te betrekken bij de vrij gesloten besluitvorming van de centrale partijelite. Ervaring kan ervoor zorgen dat men over meer bondgenoten binnen de partij beschikt en dat men het interne en externe besluitvormingsproces beter in de vingers heeft. 
Omgekeerd kan evenwel beargumenteerd worden dat een sterke fractieleider zijn fractie beter in het gareel kan houden en dus interessanter is om de partijdiscipline te bewaken (van Vonno et al., 2014). In die zin kan een sterke fractievoorzitter dus eerder de partij versterken dan de parlementaire fractie.

Vaak wordt aangenomen dat de fractievoorzitter een politicus is met een zekere ervaring en bekendheid (Devos \& Mus, 2011). In dit artikel wordt onderzocht in hoeverre dit blijkt uit onze empirische gegevens, of dit geëvolueerd is doorheen de tijd en of er op dat vlak een verschil is tussen meerderheid en oppositie. We gaan concreet na hoeveel parlementaire en ministeriële ervaring de fractieleiders sinds 1962 hadden bij de start van hun fractievoorzitterschap, wat de gemiddelde duur is van een mandaat als fractievoorzitter (wat we beschouwen als 'ervaring als fractievoorzitter') en we nemen de leeftijd van de fractievoorzitters onder de loep. De algemene redenering is dat oudere fractieleiders en fractieleiders met meer ervaring zwaarder kunnen wegen op de besluitvorming (Beckwith, 2007).

Nadat we hebben onderzocht wat de fractievoorzitters deden vóór en tijdens hun mandaat, bekijken we wat hun eerstvolgende politieke functie was ná het fractievoorzitterschap. Wat zijn de redenen voor een fractievoorzitter om het mandaat af te breken? De mate waarin het fractievoorzitterschap een springplank vormt naar een 'hoger' politiek mandaat (bv. het ministerschap) geeft een indicatie van het gewicht dat wordt gehecht aan het fractievoorzitterschap. Als vele fractieleiders doorstromen naar het ministerschap, dan betekent dit dat het fractieleiderschap enig belang heeft, aangezien het als een goede leerschool wordt aangezien.

\section{Onderzoeksvraag en methodologie}

De centrale onderzoeksvraag is in welke mate de hierboven beschreven variabelen 1) geëvolueerd zijn doorheen de tijd en 2) verschillen tussen fractieleiders van oppositie- en regeringspartijen. De afhankelijke variabelen van onze analyse zijn dus leeftijd, parlementaire en ministeriële ervaring, duur van het mandaat en vervolg op het fractievoorzitterschap. Deze geven alle, zoals hierboven besproken, een indicatie van de sterkte van de fractieleider.

We testen het effect van twee onafhankelijke variabelen, tijd en regeringsdeelname, op de sterkte van de fractieleider. Onze verwachtingen over het effect van deze twee variabelen gaan in beide richtingen. We gaan ervan uit dat de partijleiding een dominante rol speelt in het aanduiden en steunen van fractieleiders. Dat kwam bij het recente aantreden van de regering-Michel I duidelijk tot uiting toen de MR-partijleiding een persbericht verspreidde met daarin tegelijk de namen van de nieuwe ministers én van de nieuwe fractieleider in de Kamer. Het profiel van de fractieleider geeft in de eerste plaats weer hoe de partijleiding dit fractievoorzit- 
terschap ziet. De partijleiding kan de voorkeur geven aan een sterke fractieleider die waakt over de fractiediscipline en de fractie in de pas doet lopen, maar ze kan ook een zwakke fractieleider verkiezen die weinig weerwerk biedt, waardoor de partijleiding autonomer kan optreden. Hierboven hebben we beschreven dat de partijleiding doorheen de jaren nog machtiger geworden is. We gaan, ten eerste, na hoe dit zich vertaald heeft in het profiel van de fractieleider: wordt er meer en meer geopteerd voor een sterke figuur (die samen met de partijleiding de fractie onder de knoet houdt) of voor een zwakkere figuur (die weinig weerwerk biedt tegen de partijleiding)?

H1a De fractieleider is sterker geworden doorheen de tijd.

H1b De fractieleider is zwakker geworden doorheen de tijd.

Ten tweede gaan we na of er een verschil in profiel is tussen regeringspartijen en oppositiepartijen. De fractievoorzitter is voor een regeringspartij meer cruciaal, aangezien het in stand houden van het regeerakkoord en dus de regering op het spel staat. We gaan na welk effect dit heeft op het profiel: een sterkere fractieleider (die controle houdt op de fractie) of een zwakkere (die niet moeilijk doet tegenover de partijleiding).

H2a De fractieleider is sterker bij regeringspartijen.

H2b De fractieleider is zwakker bij regeringspartijen.

Om deze vragen te beantwoorden, werd een dataset opgesteld met de biografische gegevens van alle Kamerleden, Senatoren en Vlaamse Parlementsleden die ooit de functie van fractievoorzitter in deze parlementaire vergaderingen hebben bekleed. Aangezien de fracties pas officieel werden erkend in het Reglement van de Kamer in 1962 en in het Reglement van de Senaat in 1971, beschikken we over de gegevens van de Kamer- en Senaatsfractievoorzitters vanaf deze respectieve data. Voor het Vlaams Parlement beschikken we over de namen van alle fractievoorzitters vanaf de installatie van de Cultuurraad voor de Nederlandstalige Cultuurgemeenschap (voorloper van het Vlaams Parlement) op 7 december 1971. De onderzoeksperiode werd afgesloten op 26 oktober 2014, na de installatie van zowel de nieuwe Vlaamse als de federale regering, waarbij aanzienlijk wat wissels plaatsvonden inzake het fractievoorzitterschap. Fractievoorzitters die na deze datum werden aangesteld, zijn niet opgenomen in dit onderzoek.

In principe wordt de fractievoorzitter verkozen voor de duur van de volledige legislatuur. Uiteraard kan zijn/haar mandaat ook voortijdig worden stopgezet, bijvoorbeeld wanneer hij/zij wordt benoemd als lid van een regering. Anderzijds 
kan het fractievoorzitterschap meerdere legislaturen overspannen, wanneer een fractievoorzitter na de eerstvolgende verkiezingen wordt herkozen als leider van de parlementaire fractie. Wij opteerden ervoor enkel de onafgebroken mandaten als fractievoorzitter in beschouwing te nemen en geen opdeling te maken op basis van legislatuur. Toch komen sommige politici meerdere malen voor in de dataset. Dat is het geval wanneer het fractievoorzitterschap werd onderbroken (om minister, parlementsvoorzitter of even terug 'gewoon' parlementslid te worden) en daarna weer werd opgenomen. In tabel 2 zien we de volledige onderzoekspopulatie, met in de tweede kolom het aantal fractieleiders en in de derde kolom het aantal onafgebroken fractievoorzitterschappen.

TABEL 2. Onderzoekspopulatie.

\begin{tabular}{lcc}
\hline & Aantal fractievoorzitters & Aantal onafgebroken mandaten \\
\hline Kamer $(1962-\mathrm{nu})$ & 110 & 130 \\
\hline Senaat $(1971-\mathrm{nu})$ & 92 & 99 \\
Vlaams Parlement $(1971-\mathrm{nu})$ & 63 & 72 \\
\hline Totaal & 265 & 301 \\
\hline
\end{tabular}

Om een evolutieve vergelijking van de politieke carrièrekenmerken mogelijk te maken, werden de gegevens van de fractievoorzitters van Kamer, Senaat en Vlaams Parlement onderverdeeld in decennia. Het decennium waarin het onafgebroken mandaat startte, was daarbij de referentie. Zo trachtten we na te gaan hoe de politieke carrièrekenmerken van de fractieleiders over de jaren zijn geëvolueerd. Voor het onderscheid oppositiepartij-regeringspartij keken we naar het statuut van de partij bij het begin van het mandaat van de fractieleider.

De resultaten en de correlatie tussen de verschillende variabelen werden telkens ook gecontroleerd met behulp van correlatiecoëfficiënten tussen de betrokken variabele en het exacte startjaar van het mandaat. Dat gebeurde via SPSS, een softwareprogramma voor kwantitatieve analyse.

\section{Politieke carrièrekenmerken van fractieleiders (1962-2014)}

\subsection{Leeftijd}

Tussen 1962 en 2014 is de gemiddelde leeftijd van de fractievoorzitters in de Kamer, de Senaat en het Vlaams Parlement 48,2 jaar op het moment van hun aantreden. Een eerste vaststelling hierbij is dat er duidelijke leeftijdsverschillen zijn tussen de 
verschillende parlementaire vergaderingen. De Senaatsfractieleiders zijn met een gemiddelde van 51,8 jaar aanzienlijk ouder dan hun tegenhangers in de Kamer van Volksvertegenwoordigers (46,6 jaar) en in het Vlaams Parlement (45,9 jaar). Het feit dat Senatoren tot 1995 een minimumleeftijd van 40 jaar moesten hebben, lijkt zich ook te weerspiegelen in de gemiddelde leeftijd van de fractieleiders. De standaarddeviaties zijn vergelijkbaar: voor Kamer (8,2 jaar) zijn deze iets hoger dan voor het Vlaams Parlement (7,7 jaar) en de Senaat (7,9 jaar).

TABEL 3. Gemiddelde leeftijd van de fractievoorzitters in Kamer, Senaat \& Vlaams Parlement (1962-2014) (in jaren).

\begin{tabular}{lcccc}
\hline & $\begin{array}{c}\text { Kamer } \\
(1962-2014)\end{array}$ & $\begin{array}{c}\text { Senaat } \\
(1971-2014)\end{array}$ & $\begin{array}{c}\text { Vlaams Parlement } \\
(1971-2014)\end{array}$ & Totaal \\
Gemiddelde leeftijd & 46,9 & 51,9 & 45,9 & $\mathbf{4 8 , 3}$ \\
\hline
\end{tabular}

Wanneer we vervolgens de evolutie van de gemiddelde leeftijd van de fractievoorzitters bekijken, stellen we een duidelijke verjongingstrend vast: sinds de jaren'60 is de gemiddelde leeftijd van de fractieleiders alsmaar gedaald. Waar men in de jaren 60 en 70 gemiddeld ongeveer 50 jaar was, zijn fractievoorzitters vandaag zo'n vier jaar jonger. Deze verjongingstrend vond aanvankelijk vrij gestaag plaats, maar kwam in een stroomversnelling vanaf de jaren 1990 (zie grafiek 1). We stellen bovendien vast dat in de drie parlementaire instellingen afzonderlijk een duidelijke daling van de gemiddelde leeftijd plaatsvond, al is deze het meest uitgesproken voor de Senaat (o.m. door het versoepelen van het leeftijdsvereiste). Voor de Kamer lijkt de gemiddelde leeftijd recent weer te stijgen, al bereikt hij nog niet het niveau van in de jaren 60 .

Een bijkomende statistische controle leert ons dat er inderdaad een negatieve correlatie van $-0,18$ is tussen het moment van aantreden en de gemiddelde leeftijd van fractievoorzitters. ${ }^{4}$

We dienen bij deze evoluties twee zaken op te merken. Enerzijds is de gemiddelde leeftijd van alle parlementsleden samen in dezelfde periode eveneens gedaald: voor de Kamer van 52,4 jaar in 1960 tot 46,8 jaar nu (Verleden, 2013). Hierdoor wordt de pool waaruit fractieleiders kunnen gerekruteerd worden gemiddeld genomen jonger. Dat neemt niet weg dat partijen er nog steeds voor kunnen opteren om meer verantwoordelijkheden binnen de fractie (zoals het fractievoorzitterschap) toe te wijzen aan oudere parlementsleden. Dat blijkt bijvoorbeeld het geval te zijn na 2000, wanneer de gemiddelde leeftijd van Kamerleden verder daalt, terwijl de gemiddelde leeftijd van de fractieleiders in de Kamer stijgt. Er is maar een zeer beperkte correlatie van 0,04 tussen de leeftijd van de Kamerfractieleden en de Kamerfractieleiders. Er lijkt dus meer aan de hand te zijn dan een loutere reflectie van de verjonging van de parlementsleden.

RES PUBLICA • $2015-2$ 


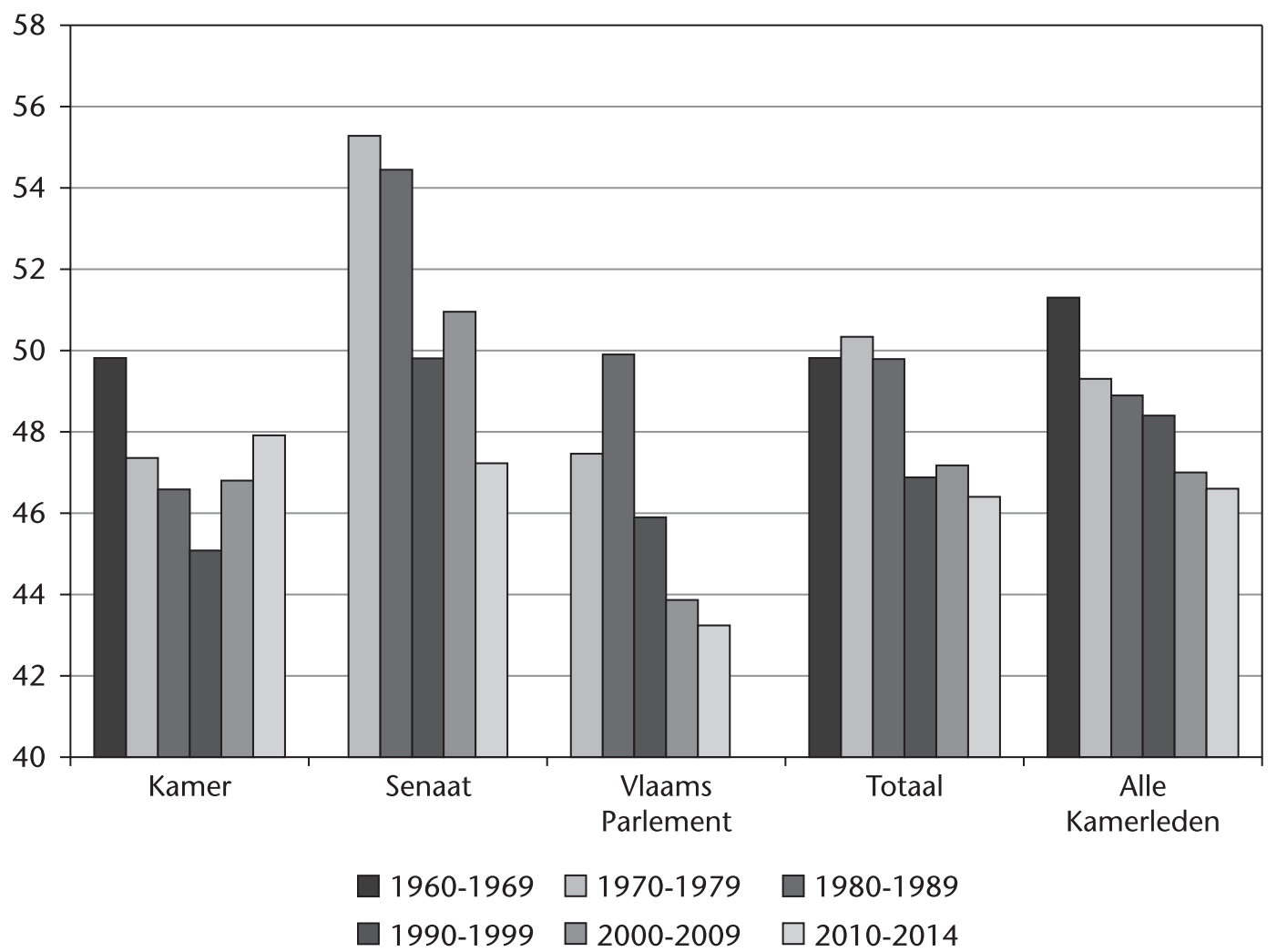

GRAFIEK 1. Gemiddelde leeftijd fractievoorzitters in de Kamer, de Senaat en het Vlaams Parlement per decennium (1962-2014).

Een tweede - vrij verrassende - vaststelling is dat de gemiddelde leeftijd bij fractievoorzitters lager ligt dan bij de overige parlementsleden. Wanneer we onze gegevens vergelijken met de algemene gegevens over Kamerleden, Senatoren en leden van het Vlaams Parlement, verzameld door Fiers, Gerard en Van Uytven (2006), stellen we vast dat fractieleiders in de periode 1981-2004 gemiddeld 47,5 jaar zijn, terwijl de overige parlementsleden gemiddeld 49,6 jaar zijn. Dat blijkt ook uit grafiek 1, waar de leeftijd van Kamerleden tot 2000 lager ligt dan de leeftijd van fractievoorzitters in de Kamer.

Onze data tonen eveneens aan dat fractievoorzitters die behoren tot de oppositie gemiddeld duidelijk jonger zijn dan fractievoorzitters die behoren tot een meerderheidspartij. Van alle fractieleiders in onze dataset behoren er 126 tot een oppositiepartij bij de start van hun mandaat. 175 fractieleiders behoren tot de meerderheid. De eersten zijn gemiddeld 47,1 jaar op het moment van hun aantreden, terwijl de laatsten gemiddeld 49,1 jaar oud zijn. De standaarddeviaties zijn met 8,5 jaar (oppositie) en 8,2 jaar (regering) vergelijkbaar.

Zoals ook Witte (1996) aangeeft, vormen fractievoorzitters van meerderheidspartijen een belangrijke verbinding met de regeringsleden. Aangezien fractievoorzitters hierbij niet enkel moeten waken over de congruentie tussen het parlementair 
werk en het partijprogramma, maar ook op de congruentie met het regeerakkoord, is een mogelijke verklaring voor het feit dat fractieleiders van de oppositie jonger zijn, dat de partijelite minder snel een jonge, 'onbezonnen' fractieleider zal aanstellen, om het broze, compromisrijke regeerakkoord niet op te blazen en de uitvoerende macht niet in problemen te brengen. Ervaring is daarnaast belangrijk om de fractie in de hand te houden. Dat deze fractieleiders intern zwaarder kunnen wegen op de besluitvorming wordt er dan blijkbaar bijgenomen door regeringspartijen.

\subsection{Opleidingsniveau}

Wat betreft het opleidingsniveau stellen we vast dat het leeuwendeel van de fractieleiders $(83,4 \%)$ een universitair diploma op zak heeft. Maar liefst $43 \%$ hiervan (35\% van alle fractieleiders) behaalde daarnaast ook een doctoraat (meestal in de rechten). Verder volgde 9,6\% van de fractieleiders niet-universitair hoger onderwijs en $4,3 \%$ enkel secundair onderwijs. ${ }^{5}$ Het opleidingsniveau is gemiddeld het hoogste in de Kamer, waar 89,2\% een universitair diploma behaalde, ten opzichte van ongeveer $79 \%$ in het Vlaams Parlement en de Senaat.

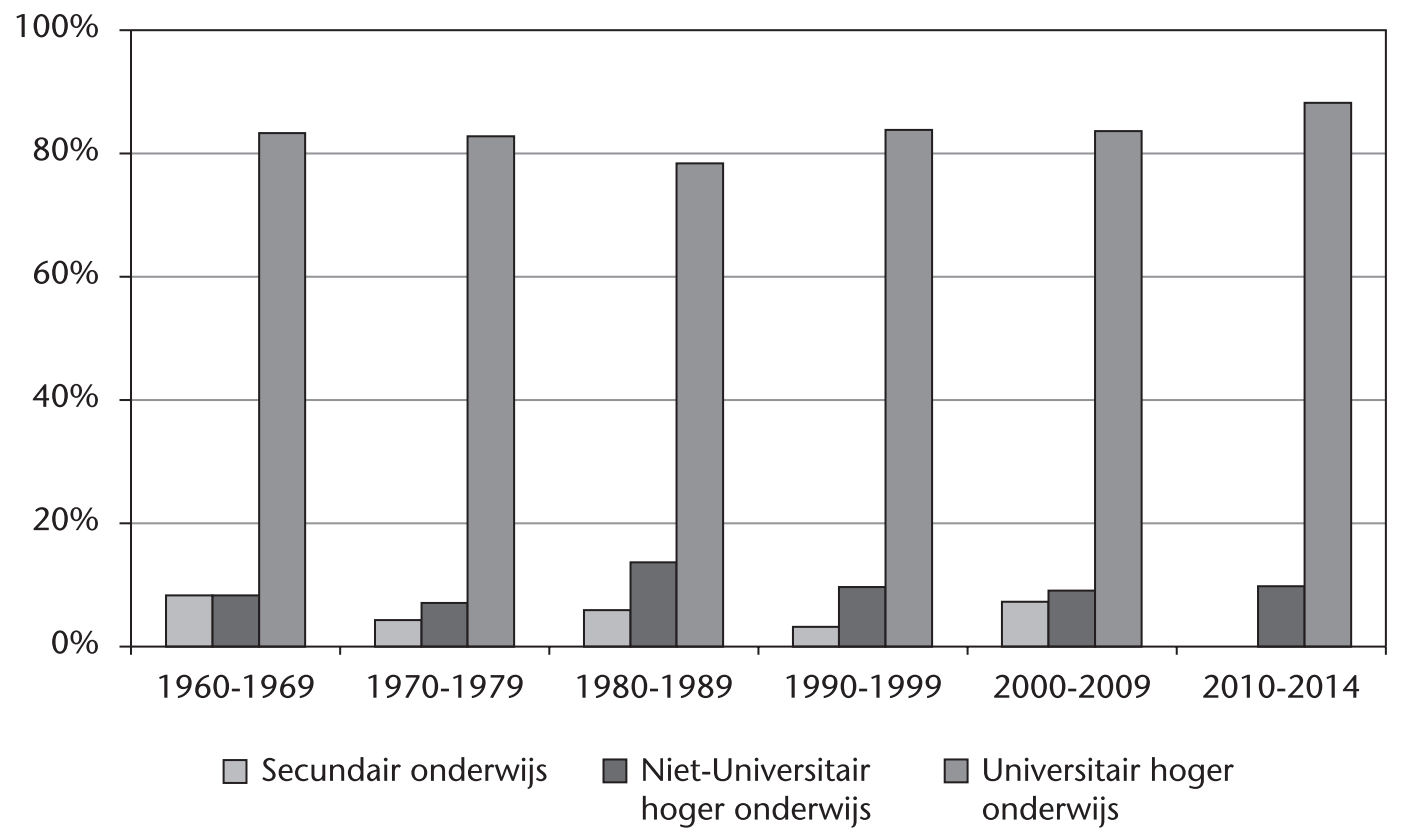

GRAFIEK 2. Opleidingsniveau van de fractievoorzitters in de Kamer, Senaat en het Vlaams parlement (1962-2014).

Wanneer we de evoluties in de tijd bekijken, zien we dat het opleidingsniveau vrij constant blijft doorheen de tijd, waarbij het aantal universitairen steeds rond de 
$83 \%$ schommelt. Ook in de onderzochte parlementen afzonderlijk blijft het opleidingsniveau stabiel.

\subsection{Parlementaire ervaring}

In hun onderzoek, stelden Depauw en Fiers (2008) dat Kamerleden steeds minder kunnen terugvallen op hun parlementaire ervaring als tegengewicht voor de relatief onervaren maar wel machtige uitvoerende macht. Maar in welke mate is dat het geval voor de fractievoorzitters? Hoeveel parlementaire ervaring hebben fractievoorzitters bij het begin van hun mandaat? Zijn de fractievoorzitters vandaag meer of minder ervaren dan hun voorgangers?

Vaak wordt gesteld dat fractievoorzitters parlementsleden zijn die vele jaren parlementaire dienst op hun conto hebben staan. Ons onderzoek leert ons dat fractievoorzitters in de Kamer, Senaat en het Vlaams Parlement bij de aanvang van het fractievoorzitterschap gemiddeld reeds 7,95 jaar zetelden in een Europees, federaal of deelstaatparlement. De standaarddeviatie bedraagt 5,4 jaar. Bovendien zijn er hierbij quasi geen verschillen te bemerken tussen de drie parlementaire instellingen (noch voor het gemiddelde noch voor de standaarddeviatie).

In grafiek 3 zien we de parlementaire ervaring van de fractieleiders in een evolutief perspectief. We zien hierbij duidelijk dat fractieleiders sinds de jaren 60 aanzienlijk aan parlementaire ervaring moeten inboeten. De voorbije vijftig jaar is de gemiddelde parlementaire ervaring van fractieleiders van ongeveer 8,9 jaar naar 7,2 jaar gezakt: een verschil van 1,7 jaar. De parlementaire anciënniteit begon te dalen vanaf de jaren 80, en dan vooral in het Vlaams Parlement en de Senaat. De correlatie tussen startjaar en parlementaire ervaring is negatief en bedraagt -0,16. Hoe recenter aangesteld, des te minder parlementaire ervaring een fractieleider heeft.

Net als bij leeftijd verloopt de daling van de parlementaire ervaring van fractievoorzitters deels parallel met deze van alle parlementsleden samen. Waar deze in de jaren 60 nog gemiddeld meer dan 8 jaar bedroeg, was deze eind jaren 90 gezakt naar iets meer dan 5 jaar (Fiers et al., 2006). Anders dan bij leeftijd, is de gemiddelde parlementaire ervaring van fractieleiders wel groter dan die van gewone parlementsleden.

In overeenstemming met de conclusies van Depauw en Fiers (2008), kan de verminderde parlementaire ervaring van fractieleiders een impact hebben op de wijze waarop zij hun rol opnemen. We doelen hiermee niet op een eventueel verzwakte structurele positie ten aanzien van de uitvoerende macht, maar wel een gewijzigde positie binnen de partijorganisatie. Zoals we reeds in de inleiding stelden, vervullen fractievoorzitters een belangrijke brugfunctie tussen de 'party in public office' en de 'party in central office'. In principe vertaalt dit zich in de tweeledige rol die ze 
kunnen vervullen ( $c f$. supra). Omdat de fractievoorzitters minder kunnen terugvallen op hun persoonlijke ervaring, zou dit echter kunnen betekenen dat ze minder sterk staan tegenover de partijelite in de 'party in central office', waardoor hun rol veeleer top-down georiënteerd is richting de parlementaire fractie in plaats van in twee richtingen.

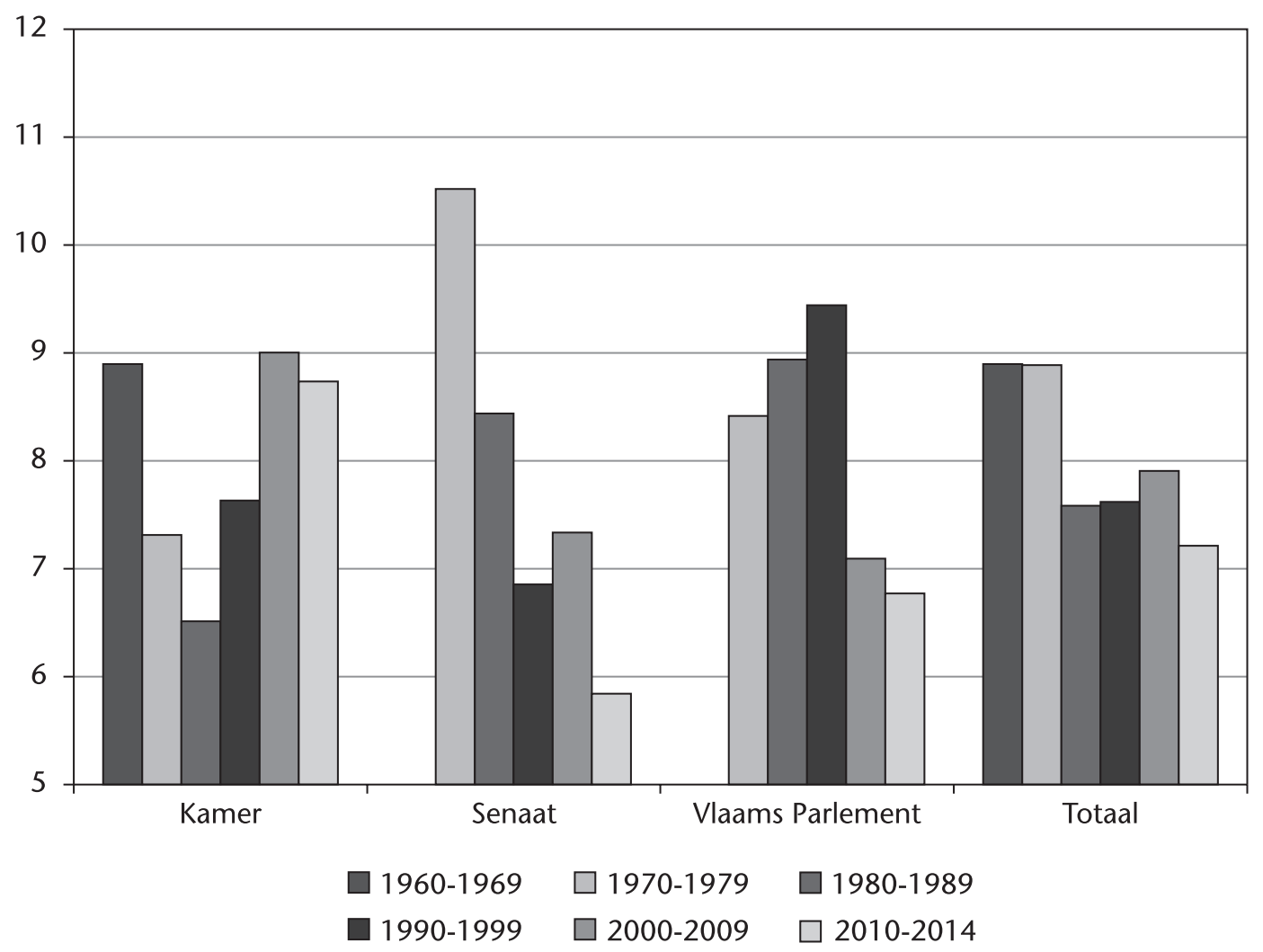

GRAFIEK 3. Parlementaire ervaring van de fractieleiders in de Kamer, de Senaat en het Vlaams Parlement per decennium (1962-2014) (in jaren).

Wanneer we een opdeling maken tussen meerderheid en oppositie, zien we eveneens duidelijke verschillen. Fractieleiders van oppositiepartijen hebben gemiddeld 7,3 jaar parlementaire ervaring. Bij meerderheidspartijen is dat gemiddeld 8,6 jaar. Fractieleiders van de oppositie zijn dus duidelijk minder ervaren dan hun collega's van de meerderheid. De standaarddeviaties zijn vergelijkbaar: 5,5 jaar (regering) versus 5,3 jaar (oppositie). Opnieuw zou dit een teken kunnen zijn dat de partijelite eerder een meer ervaren persoon aanstelt aan het hoofd van de parlementaire fractie om beter kunnen waken over de congruentie tussen het parlementair werk en het regeerakkoord. Wanneer een partij in een oppositierol zit, blijkt ze sneller geneigd jonge, minder ervaren politici aan te stellen als fractieleiders. 


\subsection{Ministeriële ervaring}

Een tweede vorm van politieke ervaring die we zullen behandelen, is de ervaring die de fractievoorzitters opbouwden als lid van een federale of regionale regering. Een ex-minister aanstellen als fractievoorzitter zou immers interessant kunnen zijn voor de partijelite, omdat deze persoon reeds het klappen van de zweep kent. Bovendien zou het fractievoorzitterschap nogal eens gegeven worden aan een voormalig minister die bij de verdeling van de ministerposten uit de boot viel (Devos \& Mus, 2011).

Van alle personen die sinds 1962 de functie van fractievoorzitter bekleedden hadden 74 personen ervaring als federaal of regionaal minister. Dat komt overeen met ongeveer $25 \%$ van alle fractievoorzitters. In de Kamer ligt dit percentage het hoogst met $28,5 \%$, terwijl het Vlaams Parlement het laagst scoort met 16,7\%. Allicht speelt hier het geringe politieke belang dat men in de beginjaren aan de Cultuurraad hechtte, een belangrijke rol (Goossens, 2003).

Gemiddeld zaten de 301 fractievoorzitters in 0,6 regeringen en waren ze 1,1 jaar minister. De standaarddeviatie bedraagt 2,7 jaar. Opgesplitst naar enkel diegenen met ministeriële ervaring $(n=74)$ zaten de fractieleiders gemiddeld in 2,3 regeringen en waren ze 4,3 jaar minister. Deze cijfers moeten evenwel genuanceerd worden, aangezien er bij de voormalige ministers enkele grote uitschieters te bemerken zijn, zoals bijvoorbeeld Laurette Onkelinx, huidig Kamerfractieleider (PS), die op het moment van haar aantreden als fractievoorzitter in 2014 maar liefst 22,6 jaar ervaring als minister op de teller had staan.

In tegenstelling tot bij de leeftijd en de parlementaire ervaring van de fractieleiders, blijven de cijfers omtrent de ervaring als minister of staatssecretaris vrij constant doorheen de volledige onderzoeksperiode. De correlaties tussen startjaar en resp. aantal regeringen en aantal jaren regeringservaring zijn slechts licht positief (resp. 0,03 en 0,09). Er is geen verschil tussen fractieleiders die in de oppositie beginnen en fractieleiders van de meerderheid wat betreft voorafgaande ministeriële ervaring.

Ook hier moeten we er rekening mee houden dat betrekkelijk weinig personen uit onze dataset vóór het fractievoorzitterschap een ministerpost had, en dat het aantal jaren ministeriële ervaring sterk varieert van persoon tot persoon.

\subsection{Duur van het fractievoorzitterschap}

Naast ervaring als parlementslid of als minister kunnen fractieleiders natuurlijk ook ervaring opbouwen als fractievoorzitter. Door meerdere jaren aan te blijven als leider van de 'party in parliament', kunnen fractieleiders hun specifieke positie binnen de partijorganisatie beter benutten en versterken. 
De gemiddelde duur van het mandaat van fractievoorzitter in de Kamer, Senaat en het Vlaams Parlement is 3,4 jaar, met een standaarddeviatie van 3,3 jaar. De nu nog zetelende fractievoorzitters werden hierbij buiten beschouwing gelaten. Opvallend aan dit cijfer is dat het lager ligt dan de gemiddelde duur van een volledige legislatuur (zowel in het Vlaams Parlement (5 jaar) als in Kamer en Senaat (voorheen 4 jaar)). Bijgevolg kunnen we hieruit afleiden dat een aanzienlijk deel van de fractieleiders geen volledige legislatuur uitzit, terwijl men in principe wel voor de volledige duur ervan wordt verkozen door de andere fractieleden. Onze data tonen bovendien slechts zeer kleine verschillen aan in de gemiddelde duur van het fractievoorzitterschap tussen de verschillende parlementen, ondanks het feit dat het Vlaams Parlement sedert 1995 een legislatuurparlement is en sinds 1999 een legislatuur kent van vijf jaar. De standaarddeviatie ligt in de Senaat $(2,8$ jaar $)$ wel een stuk lager dan in de Kamer (3,5 jaar) en het Vlaams Parlement $(3,7$ jaar).

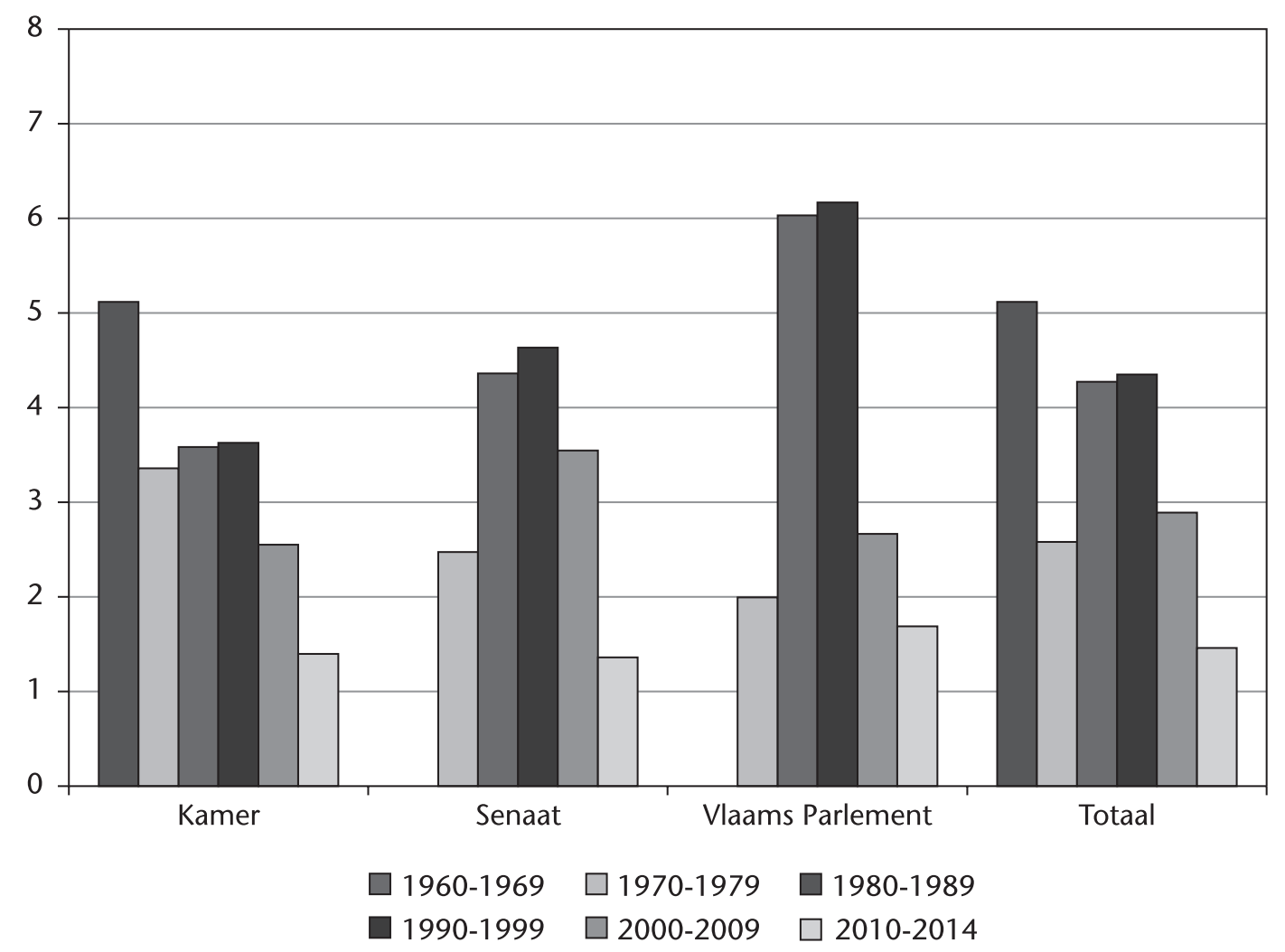

GRAFIEK 4. De gemiddelde duur van het mandaat van fractievoorzitter in Kamer,
Senaat \& Vlaams Parlement (1962-2014).

Wanneer we de gemiddelde duur van de fractievoorzitterschappen opdelen per decennium, zien we echter wel duidelijke verschillen. De fractievoorzitters die werden aangesteld in de jaren 60 bekleedden hun mandaat gemiddeld 5,1 jaar lang. 
In de jaren 70 daalt dit cijfer drastisch. De gemiddelde duur van het fractievoorzitterschap wordt gehalveerd naar 2,6 jaar. Hierbij is het belangrijk op te merken dat we voor de jaren 1962 tot 1970, zoals reeds gezegd, enkel beschikken over de gegevens van de Kamerfractievoorzitters, omdat de fracties nog niet officieel erkend werden in het Senaatsreglement en omdat de Vlaamse Cultuurraad (voorloper van het Vlaams Parlement) nog niet was opgericht. Hoewel de gemiddelde duur van het fractievoorzitterschap in de Kamer daalde in de jaren 70, is de halvering van de totale duur vooral te wijten aan het zeer lage cijfer in de Senaat en de Cultuurraad. We zien echter dat in de jaren 80 de gemiddelde duur van het fractievoorzitterschap sterk stijgt, mede onder impuls van ontwikkelingen bij de Senaatsfracties, maar zeker bij de Vlaamse Raad die steeds meer aan politiek belang wint, wat zich vertaalt in meer stabiliteit inzake het fractievoorzitterschap (Goossens, 2003). Merk op dat de gemiddelde duur van het fractievoorzitterschap in de jaren'70 en 80 vrij hoog is, ondanks het feit dat deze periode wordt gekenmerkt door een aanzienlijke politieke instabiliteit waarbij de verschillende (federale) regeringen elkaar in een snel tempo opvolgden.

Over de hele periode kunnen we echter stellen dat de gemiddelde duur van het mandaat als fractievoorzitter duidelijk daalt, een opstoot in de jaren 80 en 90 niet te na gesproken. We zien dat de gemiddelde duur van de fractievoorzitterschappen in Kamer, Senaat en Vlaams Parlement sterk convergeren vanaf de jaren 2000 tot een beperkte duur van gemiddeld 2,9 jaar in het eerste decennium van 2000 en zelfs tot 1,5 jaar tussen 2010 en 2014. Opnieuw werden de nog zetelende fractievoorzitters hier buiten beschouwing gelaten. Er is een negatieve correlatie tussen startjaar en duur van het mandaat van $-0,17$, die evenwel verdwijnt als zetelende fractieleiders buiten beschouwing worden gelaten.

In tegenstelling tot bij de leeftijd en de parlementaire ervaring, zijn er geen duidelijke verschillen te bemerken tussen oppositie en meerderheid wat betreft de duur van het fractievoorzitterschap. Fractieleiders van oppositie en van meerderheid blijven over de volledige onderzoeksperiode gemiddeld ongeveer 3,4 jaar aan als fractieleider.

\subsection{Wat na het fractievoorzitterschap?}

We zagen reeds dat fractievoorzitters gemiddeld 3,4 jaar aanblijven. De laatste jaren is deze duur zelfs nog verder gezakt. Het feit dat de gemiddelde duur van het fractievoorzitterschap lager ligt dan de gemiddelde duur van een legislatuur, wijst erop dat nogal wat fractieleiders hun mandaat voortijdig beëindigen. Daarom rest ons de logische vraag wat er gebeurt met fractievoorzitters na hun mandaat.

We analyseren hiervoor het eerstvolgende politieke mandaat dat de fractieleiders in onze dataset opnamen na hun mandaat als voorzitter van een parlementai- 
re fractie in de Kamer, de Senaat of het Vlaams Parlement. Dit is om verschillende redenen interessant.

Ten eerste krijgen we op deze manier een beter zicht op de redenen om het fractievoorzitterschap af te breken, wat vrij frequent gebeurt (cf. supra). Bovendien kunnen we hierdoor een beter zicht krijgen op het parlement als rekruteringspool voor mandaten die hoger staan in de politieke machtshiërarchie. Ten derde leert dit ons wat de plaats is van de fractievoorzitters in de politieke pikorde: voor welk politiek mandaat is men bereid het fractievoorzitterschap op te geven? Ten vierde staat dit ons - samen met de andere vergaarde informatie - toe verschillende 'type fractievoorzitterschappen' te onderscheiden. Vormt het fractievoorzitterschap een springplank voor een hogere functie? Wordt het gezien als een troostprijs voor een politicus die naast een ministerportefeuille greep? Of is het een 'fin-de - carrièrebeloning' voor een hardwerkend parlementslid? Zijn er ook hier duidelijke evoluties doorheen de tijd?

Wanneer we de dataset bekijken, valt meteen de grote diversiteit aan 'vervolgjobs' op. Sommige fractieleiders schoppen het tot parlementsvoorzitter, minister, partijvoorzitter of zelfs premier of minister-president. Anderen worden terug 'gewoon' parlementslid en nog anderen stoppen volledig met de politiek. Opvallend is dat recent sommige fractieleiders na het aflopen van hun mandaat, hun 'carrière als fractievoorzitter' verderzetten in een andere instelling, en bijvoorbeeld van het Vlaams Parlement naar de Senaat verhuizen.

Wanneer we de nog zetelende fractievoorzitters buiten beschouwing laten, stellen we vast dat $43,2 \%$ een lager politiek mandaat ('gewoon' parlementslid) bekleedt na het fractievoorzitterschap, 38,5\% stoot door naar een hoger politiek mandaat (minister, partijvoorzitter, parlementsvoorzitter of lid van het Grondwettelijk Hof) en 5,4\% wordt fractievoorzitter in een ander parlement. 12, \% zegt de nationale politiek definitief vaarwel na het fractievoorzitterschap. Globaal gezien is het aantal fractieleiders dat een minder hoog mandaat krijgt na afloop van het fractievoorzitterschap groter dan het aantal fractieleiders dat doorstoot tot de hogere politieke echelons. Overigens maken de Kamerfractieleiders het meeste kans op promotie: $46,7 \%$ stroomt door naar een belangrijkere politieke functie. In het Vlaams Parlement en de Senaat is dit respectievelijk 36,9\% en 28,6\%.

Wanneer we bekijken hoe deze gegevens zijn geëvolueerd doorheen de tijd, stellen we vast dat fractievoorzitters na 2000 veel minder doorstoten naar hogere politieke mandaten dan ervoor. Grafiek 5 laat zien dat het fractievoorzitterschap in de Kamer initieel helemaal geen opstap was naar een hoger mandaat. Vanaf de jaren 70 neemt het percentage fractieleiders dat doorstoot naar een hoger mandaat toe, om tot en met de jaren 90 constant te blijven rond iets meer dan 40\%. Na 2000 neemt de aantrekkelijkheid van het fractievoorzitterschap voor een verdere carrière sterk af: in het eerste decennium stoot slechts $35 \%$ van de fractieleiders door naar een hoger mandaat, en in de jongste jaren is dit verder gezakt naar $24, \%$. De evo- 
lutie lijkt duidelijk: het fractievoorzitterschap is minder dan voorheen een springplankfunctie voor politieke mandaten die hoger in de politieke pikorde staan.

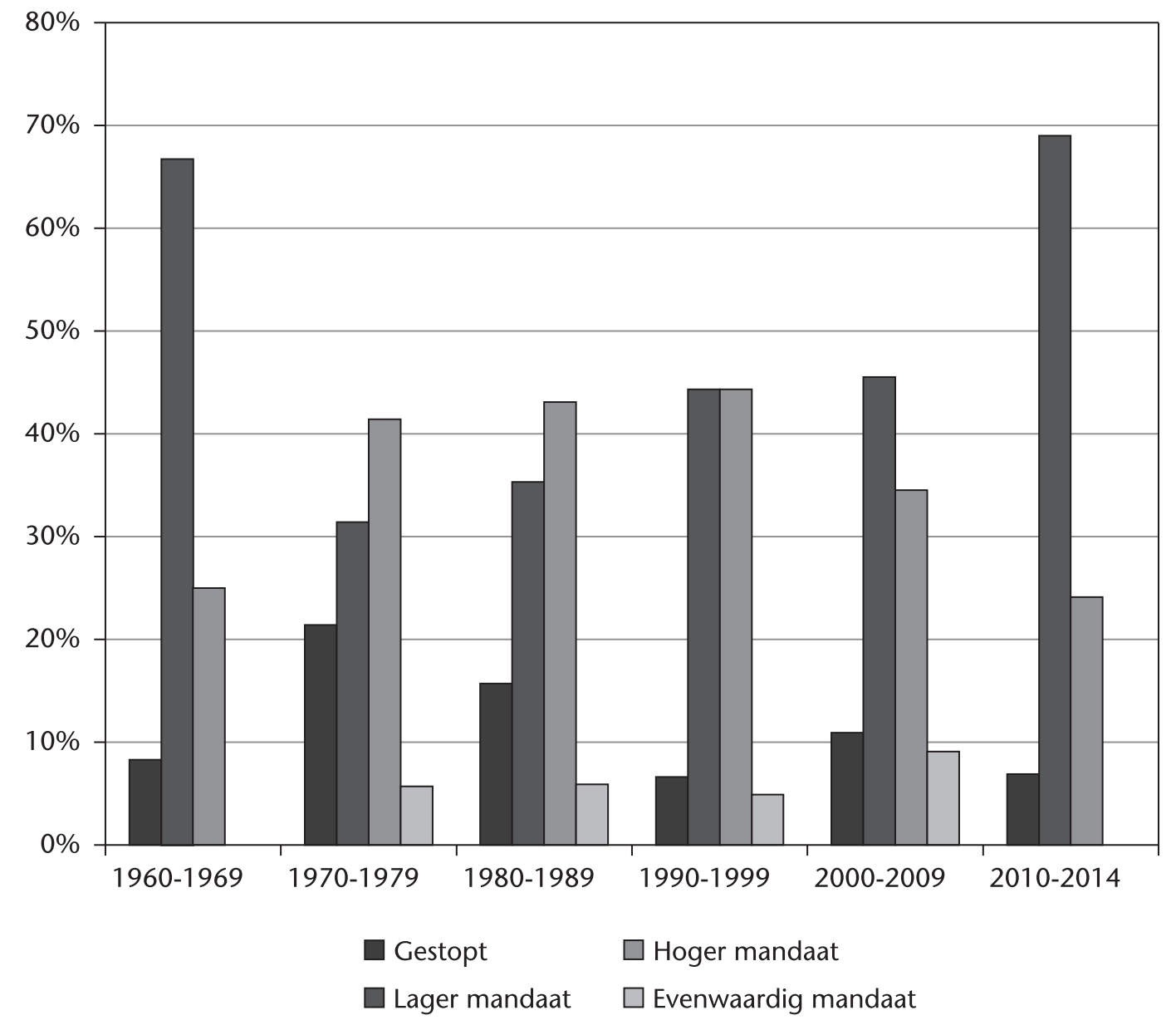

GRAFIEK 5. Fractievoorzitterschap als springplank naar een hoger mandaat per decennium (1962-2014).

Omdat het aantal observaties voor recente jaren te klein is voor een opdeling per parlement, zijn deze niet opgenomen in de grafiek. Nog zetelende fractieleiders worden immers niet in de analyse opgenomen. Over de volledige periode die we hier analyseren, kunnen wel een aantal verschillen genoteerd worden tussen parlementen (telkens ongeveer 7\%). Het percentage stoppers ligt in de Senaat (met $25 \%$ ) een stuk hoger dan in de andere twee parlementen. In de Kamer is het percentage fractieleiders dat doorstroomt naar een hoger mandaat (45) dan weer groter dan in andere parlementen (resp. 37 en 29 voor Vlaams Parlement en Senaat).

Er zijn geen verschillen te bemerken tussen meerderheid en oppositie: zowel fractieleiders in de oppositie als in de meerderheid hebben gemiddeld ongeveer $40 \%$ of iets minder kans op een hoger mandaat na het fractievoorzitterschap. 


\section{Naar een typologie van fractieleiders}

Het geschetste politieke profiel van de fractieleiders, als brug tussen de 'party in public office' en de 'party in central office' in België, staat ons toe een typologie te ontwikkelen van deze parlementaire leider. Meer in het bijzonder combineren we hiervoor twee van de voornaamste hierboven besproken variabelen. De eerste variabele, de politieke ervaring, ${ }^{6}$ heeft betrekking op de politieke carrière vóór het fractievoorzitterschap en kan beschouwd worden als een belangrijk selectiecriterium die de partij hanteert bij de aanstelling van een nieuwe fractieleider. De tweede variabele, het eerstvolgende politieke mandaat na het fractieleiderschap, heeft betrekking op de carrière na het fractievoorzitterschap en kan beschouwd worden als een waardeoordeel over hoe deze persoon zijn rol als fractieleider volgens de partijleiding en/of de kiezers heeft ingevuld. Door deze twee variabelen te combineren, verkrijgen we vijf types fractievoorzitters. ${ }^{\text {? }}$

TABEL 4. Typologie van fractieleiders in België (met vermelding percentages t.o.v. totaal aantal fractieleiders)

\begin{tabular}{|c|c|c|c|c|}
\hline & & \multicolumn{3}{|c|}{ Politiek mandaat na het fractievoorzitterschap } \\
\hline & & Lager mandaat of gestopt & Evenwaardig mandaat & Hoger mandaat \\
\hline \multirow{2}{*}{$\begin{array}{l}\text { Politieke } \\
\text { ervaring }\end{array}$} & Weinig ervaring & $\begin{array}{l}\text { Snel in, snel out } \\
\qquad(9,7 \%)\end{array}$ & \multirow{2}{*}{$\begin{array}{l}\text { Level-hoppers } \\
\qquad \begin{array}{c}(5, \%) \ldots \\
\ldots\end{array}\end{array}$} & $\begin{array}{c}\text { Snelle springplank } \\
(10,4 \%)\end{array}$ \\
\hline & Veel ervaring & $\begin{array}{l}\text { Trouwe soldaten } \\
\qquad(46,7 \%)\end{array}$ & & $\begin{array}{c}\text { Geleidelijke klimmers } \\
\qquad(27,7 \%)\end{array}$ \\
\hline
\end{tabular}

Het eerste type hebben we gelabeld als 'snel in, snel out'. Het gaat over parlementsleden die met relatief weinig parlementaire ervaring fractieleider worden, maar daarna terug gewoon parlementslid worden of zelfs helemaal stoppen. Voorbeelden hiervan zijn Rik Torfs (CD\&V, Senaat) en Annemie Van de Casteele (VU, Kamer). De duur van hun fractievoorzitterschap is korter dan gemiddeld, het gaat vooral om vrouwen en we vinden hen vooral terug in oppositiepartijen. Iets meer dan $9 \%$ van de fractieleiders valt in deze categorie.

Het tweede type zijn de 'trouwe soldaten'. Dit zijn personen die vooraleer ze fractieleider worden al heel wat parlementaire ervaring hebben opgedaan, die langer dan gemiddeld aanblijven als fractieleider en daarna een lager mandaat opnemen of helemaal stoppen. Een voorbeeld van dit type is Dirk Van der Maelen (sp.a, Kamer). We vinden ze vooral terug bij regeringspartijen. Bijna de helft van alle fractieleiders valt in deze categorie.

Het derde type zijn de zogenaamde 'level-hoppers' (zie ook Fiers, 2001). Deze beperkte groep zet zijn mandaat van fractievoorzitter voort op een ander beleidsniveau. Dit fenomeen is typisch voor multilevel-systemen, waar meerdere beleidsniveaus 
zulke overstappen mogelijk maken. We vinden dit type fractieleider vooral terug in regeringspartijen, hun mandaat is korter dan gemiddeld en het zijn exclusief mannen. Een voorbeeld van dit type is Bart Tommelein (OpenVld, eerst Kamer, daarna Senaat).

Een vierde type hebben we gecatalogeerd als 'snelle springplank'. Het gaat over relatief onervaren fractieleiders, die naderhand wel een grote carrière maken. Ze blijven iets langer aan dan gemiddeld en we vinden ze iets vaker in de Kamer. Voorbeelden zijn voormalig eerste minister Yves Leterme (CD\&V, Kamer) en huidig minister van Binnenlandse Zaken Jan Jambon (N-VA, Kamer). Ongeveer 10\% van alle fractieleiders valt in deze categorie.

Een laatste type is dat van de 'geleidelijke klimmers'. Dit zijn personen die hun carrière geleidelijk opbouwen. Ze leren eerst gedurende geruime tijd de stiel kennen als parlementslid, doen dan verder ervaring op als fractieleider om uiteindelijk door te groeien tot het ministerschap. Ze komen vooral voor in de Kamer. Voorbeelden zijn de huidige Vlaamse minister-president Geert Bourgeois (N-VA, Kamer) en Louis Tobback (sp.a, Kamer).

Deze typologie opent interessante perspectieven voor verder onderzoek. Zo kan onder meer onderzocht worden of de selectiemethode of de wijze van functioneren verschilt tussen de verschillende types die hier worden onderscheiden.

\section{Conclusies}

In deze eerste, verkennende studie onderzochten we het politieke profiel van de fractievoorzitters in het Vlaams Parlement, de Kamer en de Senaat. Deze functie vormt een unieke verbinding tussen de 'party in central office' (zijnde de partijleiding) en de 'party in public office' (in dit geval de parlementaire fractie). Bevindingen over het profiel van de fractieleiders vertellen ons dan ook ruimer iets over de verhouding tussen deze twee partijgezichten.

Een eerste vraag die we behandelden, is of dit profiel gewijzigd is sinds de eerste fractieleider officieel werd aangeduid in 1962. Onder impuls van verschillende maatschappelijke en politieke verschuivingen zijn er immers verschillende aanwijzingen dat ook de interne partijverhoudingen - meer bepaald tussen de 'party in public office' en de 'party in central office', waartussen de fractievoorzitter pivoteert - zijn gewijzigd. We gaan ervan uit dat partijen doorheen de jaren een steeds grotere vinger in de pap hebben gekregen bij het aanduiden van de fractieleider. Het is evenwel niet duidelijk welk effect dit zal hebben: prefereren partijen een sterke fractieleider die zijn fractie in het gareel houdt, of een zwakke fractieleider die hen weinig weerwerk biedt? We hebben met behulp van een kwantitatieve analyse van de biografische gegevens van de fractievoorzitters gekeken hoe de politieke carrièrekenmerken van deze politici zijn gewijzigd. 
Een tweede vraag die aan bod kwam, is of er verschillen in dit profiel zijn tussen fractieleiders van oppositiepartijen en van regeringspartijen. De fractiecohesie, die fractieleiders moeten bewaken, is crucialer voor regeringspartijen, aangezien het voortbestaan van de regering daarvan afhangt.

Wat de evolutie doorheen de tijd betreft, stellen we vast dat het merendeel van de resultaten wijzen op een 'verzwakking' van het profiel de fractieleider doorheen de tijd. Fractievoorzitters worden niet alleen jonger doorheen de tijd, ze kunnen steeds minder terugvallen op lange politieke ervaring als ze aan hun mandaat beginnen. Dat blijkt ten eerste uit het feit dat de gemiddelde voorafgaande parlementaire ervaring van fractieleiders stelselmatig is afgenomen sinds het begin van onze metingen. Ten tweede blijven fractieleiders vandaag minder lang aan als fractievoorzitter dan vroeger. Daarnaast lijken fractieleiders minder dan voorheen na hun mandaat te kunnen doorstromen naar een hoger mandaat, zoals het partijvoorzitterschap of het ministerschap. De gemiddelde ministeriële ervaring, die vrij beperkt is, blijft daarentegen wel stabiel doorheen de tijd.

We argumenteerden dat politieke ervaring cruciaal was voor fractieleiders omwille van de specifieke positie die ze innemen binnen partijorganisaties. Om een tegenmacht te kunnen bieden tegen de 'party in central office', verwachten we dat meer ervaren fractieleiders gemakkelijker en krachtiger de democratisch verkozen leden van de parlementaire fracties kunnen betrekken in de partijbesluitvorming. Omdat fractieleiders steeds jonger zijn, over minder parlementaire bagage beschikken en minder lang aanblijven als fractievoorzitter, bestaat de vrees dat fractievoorzitters althans op basis van hun politiek profiel - structureel aan macht inboeten binnen partijorganisaties, en dat zo dus de 'party in central office' versterkt wordt ten nadele van de 'party in public office'. Het is interessant om te noteren dat in een land waar de particratie en de dominantie van partijen over parlementaire fracties al stevig uitgebouwd was, er zich een verdere verzwakking van die fractie heeft voorgedaan als we kijken naar het profiel van de fractieleider. Die specifieke evolutie stemt overeen met een meer algemene evolutie naar grotere invloed van de partij, ook in landen waar die dominantie van oudsher minder groot was (Heidar \& Koole, 2000).

De partijleiding heeft er dus blijkbaar de voorkeur aan gegeven om haar toenemende macht aan te wenden om zwakkere fractieleiders tegenover zich te krijgen. $\mathrm{Al}$ dienen we voor ogen te houden dat deze evolutie deels een weerspiegeling is van de veranderde samenstelling van de parlementaire fractie waaruit de fractieleider wordt gekozen.

De verschillen tussen oppositie en meerderheid zijn, ten tweede, interessant en kunnen een aanzet zijn tot bijkomend onderzoek. De parlementsleden die op het moment van hun aantreden als fractievoorzitter behoren tot de oppositie, blijken gemiddeld jonger en minder ervaren te zijn dan hun collega's uit de meerderheid. Dit kan erop wijzen dat regeringsdeelname een belangrijke factor is bij de selectie van een nieuwe fractievoorzitter, in de zin dat regeringspartijen eerder een beroep 
doen op iemand die de knepen van het vak kent om de parlementaire fracties in het gareel te doen lopen. Eens de fractieleiders zijn aangesteld, verdwijnen de verschillen tussen meerderheid en oppositie echter: fractieleiders uit beide kampen blijven gemiddeld ongeveer even lang aan en nadat hun mandaat is beëindigd hebben ze evenveel kans op een hoger politiek mandaat.

Deze verkennende kwantitatieve studie, die enkele interessante inzichten oplevert, opent enkele pistes voor verder onderzoek naar de positie van de fractievoorzitter in België. Zo zou, naar analogie met het partijvoorzitterschap (Fiers, 1998; Pilet \& Wauters, 2014) het selectieproces van de fractievoorzitter verder uitgespit kunnen worden, waarin kan nagegaan worden of het werkelijk de partijleiding is die dit proces stuurt, zoals we hebben aangenomen in dit artikel. Hier kan aandacht zijn voor zowel de formele en werkelijke besluitvormers, als voor de criteria die er gehanteerd worden.

Ook de eigenlijke rolinvulling (Searing, 1994) van het fractievoorzitterschap kan verder onderzocht worden. Bijzonder relevant is om na te gaan hoe fractieleiders zelf invulling geven aan de verhouding tussen de 'party in central office' en de 'party in public office', welke van beide componenten voor hen prioritair is, in welke richting deze relatie verloopt (top-down versus bottom-up), en of daar een evolutie doorheen de tijd te bespeuren valt. De verschillen in profiel tussen regeringspartijen en oppositiepartijen zijn hier ook interessant. De vraag rijst of regeringsdeelname zorgt voor een andere invulling van het fractievoorzitterschap. Tot slot kunnen ook de carrière-effecten van fractieleiders gerelateerd worden aan de invulling die ze gegeven hebben aan hun mandaat. De redenering zou dan bijvoorbeeld kunnen zijn dat fractieleiders die na hun mandaat doorstoten naar het ministerschap hun mandaat anders hebben opgevat dan fractieleiders die daarna terug gewoon parlementslid worden.

\section{Noten}

1. Met dank aan de diensten Documentatie en Archief van het Vlaams Parlement, de Kamer en de Senaat.

2. Het betreft hier de jongste versies van de diverse partijstatuten, die werden geraadpleegd in maart 2015.

3. Het totale aantal onafgebroken mandaten ligt hoger dan het aantal fractievoorzitters, aangezien verschillende personen meermaals voorkomen in de dataset, omdat zij, na het fractievoorzitterschap te hebben onderbroken voor een ander politiek mandaat, opnieuw werden aangesteld als fractieleider binnen datzelfde parlement. 
4. Aangezien we werken met gegevens over de hele populatie van fractieleiders, zijn statistische significantietesten hier niet aan de orde.

5. Van 2,7\% fractievoorzitters is het opleidingsniveau ongekend;

6. We nemen 4 jaar (dit is één legislatuur) als afbakening om een onderscheid te maken tussen personen met weinig en veel voorafgaande ervaring. Daarnaast catalogeren we personen met voorafgaandelijke ministeriële ervaring eveneens als personen met veel ervaring.

7. Omwille van het beperkte aantal observaties voor fractieleiders die een evenwaardig mandaat opnemen na afloop van hun fractievoorzitterschap, maken we hier geen onderscheid tussen degenen met weinig en met veel ervaring.

\section{Bibliografie}

Andeweg, R.B. (2000). Fractiocracy? Limits to the Ascendancy of the Parliamentary Party groups in Dutch Politics, In K. Heidar \& R. Koole (Eds.), Parliamentary Party Groups in European Democracies - Political Parties Behind Closed Doors (pp. 89105). London: Routledge.

Beckwith, K. (2007). Numbers and Newness: The Descriptive and Substantive Representation of Women. Canadian Journal of Political Science, 40(1), 27-49.

Bowler, S., Farrel, D. \& Katz, R. (Eds.) (1999). Party Discipline \& Parliamentary Government. Columbus: Ohio State University Press.

Dalton, R., McAllister, I. \& Wattenberg, M. (2005). Political Parties and Their Publics. In K. Luther \& F. Müller-Rommel (Eds.), Political Parties in the New Europe (pp. 19-42). Oxford: Oxford University Press.

Dalton, R. \& Weldon, S. (2005). Public Images of Political Parties: A Necessary Evil? West European Politics, 28(5), 931-951.

Dassoneville, R. \& Baudewyns, D. (2014). Volatiliteit: veel beweging, geen aardverschuiving. Partirep-verkiezingsonderzoek. Samenleving en Politiek, 21(7), 5-16.

Depauw, S. (2005). Rebellen in het parlement. Fractiecohesie in de Kamer van Volksvertegenwoordigers (1991-1995). Leuven: Universitaire Pers.

Depauw, S. \& Fiers, S. (2008). Komen onze Kamerleden ervaring tekort? Res Publica, 50(2), 98- 108.

Depauw, S. \& Martin, S. (2008). Legislative Party Discipline and Cohesion in Comparative Perspective. In K. Benoit \& D. Gianetti (Eds.). Intra-party Politics and Coalition Governments (pp. 103-120). London: Routledge.

RES PUBLICA • $2015-2$ 
Devos, C. \& Mus, M. (2011). Staat en Parlement. In C. Devos (Ed.) Een plattegrond van de macht. Inleiding tot de politiek en de politieke wetenschappen (pp. 297-344). Gent: Academia Press.

Dewachter, W. (2002). De mythe van de parlementaire democratie. Leuven: Acco.

Dewachter, W. \& Depauw, S. (Eds.) (2006). Een halve eeuw partijbureau in België. Leuven: Acco.

De Winter, L. (1992). The Belgian Legislator. Florence: European University Institute.

De Winter, L. (1998). Parliament and Government in Belgium: Prisoners of Partitocracy. In P. Norton (Ed.), Parliaments and Governments in Western Europe (pp. 97-122). London: Frank Cass.

De Winter, L., Della Porta, D. \& Deschouwer, K. (1996). Partitocracies between Crises and Reform: The Cases of Italy and Belgium. Res Publica, 38(1), 215-494.

De Winter, L. \& Dumont, P. (2000). PPG's in Belgium: Subject of Partitocratic Dominion. In K. Heidar \& R. Koole (Eds.). Parliamentary Party Groups in European Democracies. Politics Behind Closed Doors (pp. 106-129). New York: Routledge.

Drummond, A. (2006). Electoral Volatility and Party Decline in Western Democracies: 1970-1995. Political Studies, 54(3), 628-647.

Duverger, M. (1954). Political Parties: Their Organisation and Activities in the Modern State. London: Methuen.

Fiers, S. (1998). Partijvoorzitters in België. Of "le parti, c'est moi?". Leuven: Acco.

Fiers, S. (2001). Level-hopping in Multi-level Political Environments: Parliamentary Careers in Belgium and France. Paper Presented at ECPR Joint Sessions, Grenoble, 6-11 April 2001.

Fiers, S., Gerard, E, \& Van Uytven, A. (2006). De uitverkorenen. De federale en Vlaamse parlementsleden (1946-2004). In S. Fiers \& H. Reynaert (Eds.) Wie zetelt? De gekozen politieke elite in Vlaanderen doorgelicht (pp. 87-111). Tielt: Lannoo Campus.

Fiers, S. \& Reynaert, H. (Eds.) (2006). Wie zetelt? De gekozen politieke elite in Vlaanderen doorgelicht. Tielt: Lannoo Campus.

Goossens, M. (2003). Dertig jaar Vlaams Parlement: historiek en dynamiek van een parlementaire instelling 1971-2002. Kapellen: Uitgeverij Pelckmans.

Hays, D. (2005). Candidate Qualities through a Partisan Lens: A Theory of Trait Ownership. American Journal of Political Science, 49(4), 908-923.

Heidar, K. (2013). Parliamentary Party Groups: To Whom is the Midfield Accountable? In W.C. Müller \& H.M. Narud (Eds.), Party Governance and Party Democracy (pp. 115-136). New York: Springer.

Heidar, K. \& Koole, R. (2000c). Parliamentary Party Groups Compared. In K. Heidar \& R. Koole (Eds.), Parliamentary Party Groups in European Democracies: Political Parties Behind Closed Doors (pp. 248-270). London: Routledge.

Katz, R. (2005). Internal Life of Parties. In K. Luther \& F. Müller-Rommel (Eds.), Political Parties in the New Europe. Political and Analytical Challenges (pp. 87-118). Oxford: Oxford University Press. 
Katz, R. \& Mair, P. (1994). How Parties Organize: Change and Adaptation in Party Organizations in Western Democracies. London: Sage.

Katz, R. \& Mair, P. (1995). Changing Models of Party Organization and Party Democracy. The Emergence of the Cartel Party. Party Politics, 1(1), 5-28.

Kirchheimer, O. (1966). The Transformation of West European Party Systems. In J. Lapombera \& M. Weiner (Eds.). Political Parties and Political Development (pp. 177200). Princeton: Princeton University Press.

Krouwel, A. (2006). Party Transformations in European Democracies. New York: State University.

Luther, K. \& Müller-Rommel, F. (Eds.) (2005). Political Parties in the New Europe. Political and Analytical Challenges. Oxford: Oxford University Press.

Norton, P. (1993). Does Parliament Matter? New York: Harvester Wheatsheaf.

Pattyn, V., Van Hecke, S., Brans, M, \& Libeer, T. (2014). Tussen politieke partijen en think tanks: Een verkennende analyse van de Vlaamse partijstudiediensten. Res Publica, 56(3), 293-316.

Persson, T. \& Hermansson, J. (2013). The 'Presidentialisation' Thesis Revisited: Lessons from the Swedish Case. Paper gepresenteerd op 'The Importance of Constitutions', Istanbul, 23-25 October 2013.

Pilet, J-B. \& Cross, W. (Eds.) (2014). The Selection of Political Party Leaders in Contemporary Modern Democracies: A Comparative Study. Oxford: Routledge.

Pilet J.-B. \& Wauters, B. (2014). The Selection of Party Leaders in Belgium. In J.-B. Pilet \& W. Cross (Eds.), The Selection of Political Party Leaders in Contemporary Modern Democracies: A Comparative Study (pp. 30-46). Oxford: Routledge.

Poguntke, T. (2005). Party Organizational Linkage: Parties without Firm Social Roots? In K.-R. Luther \& F. Müller-Rommel (Eds.) Political Parties in the New Europe (pp. 4362). Oxford: Oxford University Press.

Searing, D. (1994). Westminster's World. Understanding Political Roles. Harvard: Harvard University Press.

Searing, D. \& Game, C. (1977. Horses for Courses: The Recruitment of Whips in the British House of Commons. British Journal of Political Science, 7(3), 361-385.

Steyvers, K. (2014). Van ankerpunt tot leeg schip: de evolutie van politieke partijen. In C. Devos (Ed.), België \# 2014: een politieke geschiedenis van morgen (pp. 115-143). Gent: Borgerhoff \& Lamberigts.

Van Biezen, I., Mair, P. \& Poguntke,T. (2012). Going, Going, ... Gone? The Decline of Party Membership in Contemporary Europe. European Journal of Political Research, 51(1), 24-56.

Van Holsteyn, J. \& Andeweg, R. (2010). Demoted Leaders and Exiled Candidates: Disentangling Party and Person in the Voter's mind. Electoral Studies, 29(4), 628-635.

Van Vonno, C., Itzkovitch Malka, R., Depauw, S., Hazan, R.Y. \& Andeweg, R.B. (2014). Agreement, Loyalty and Discipline: A Sequential Approach to Party Unity. In K. De- 
schouwer \& S. Depauw (Eds.), Representing the People. A Survey among Members of Statewide and Sub-state Parliaments (pp. 110-136). Oxford: Oxford University Press. Verleden, F. (2013). De toegang tot de parlementaire elite. Politieke rekrutering en lijstvorming in België in historisch perspectief. Paper gepresenteerd op het Politicologenetmaal 2013, Gent, 30-31 mei 2013.

Westmacott, M. (1983). Whips \& Party Cohesion. Canadian Parliamentary Review, 6(3), 14-19.

Witte, E. (1996). Politiek en democratie. Brussel: VUBPress. 